\title{
TITLE:
}

\section{LICHOMOLGID COPEPODS (CYCLOPOIDA) ASSOCIATED WITH THE CORAL GENUS MONTIPORA IN THE MOLUCCAS}

\section{$\operatorname{AUTHOR}(\mathrm{S}):$}

Humes, Arthur G.

\section{CITATION:}

Humes, Arthur G.. LICHOMOLGID COPEPODS (CYCLOPOIDA) ASSOCIATED WITH THE CORAL GENUS MONTIPORA IN THE MOLUCCAS. PUBLICATIONS OF THE SETO MARINE BIOLOGICAL LABORATORY 1978, 24(4-6): 387-407

ISSUE DATE:

1978-10-15

URL:

http://hdl.handle.net/2433/175973

RIGHT: 


\title{
LICHOMOLGID COPEPODS (GYCLOPOIDA) ASSOCIATED WITH THE GORAL GENUS MONTIPORA IN THE MOLUCGAS
}

\author{
ARTHur G. HUMES \\ Boston University Marine Program, Marine Biological Laboratory, \\ Woods Hole, Massachusetts, U.S.A. 02543
}

With Text-figures $1-12$

\begin{abstract}
Five species of lichomolgid copepods are reported from the scleractinian coral genus Montipora in the Moluccas (Ambon, Banda, Geram). Allopodion mirum n. gen., n. sp., Kawanolus parangensis $\mathbf{n}$. gen., n. sp., and Haplomolgus subdeficiens n. sp. live with Montipora sp. $c f . M$. undata Bernard. Odontomolgus forhani is associated with both Montipora compressa (Esper) and Montipora prolifera (Brueggemann). Haplomolgus montiporae Humes \& Ho, 1968, a species previously known only from Madagascar, lives with Montipora compressa, a new host.
\end{abstract}

Previous records of cyclopoid copepods associated with the scleractinian genus Montipora are entirely from the Indian Ocean. The copepods are: (1) Asteropontius corallophilus Stock, 1966 (Asterocheridae) with three different species on Montipora in Mauritius (Stock, 1966); (2) Haplomolgus montiporae Humes and Ho, 1968 (Lichomolgidae) with Montipora sinensis, Montipora sp. cf. M. stellata Bernard, and Montipora sp. in Madagascar (Humes and Ho, 1968a), and with Montipora sp. in Madagascar (Humes and Stock, 1973); (3) Indoclausia bacescui Sebastian and Pillai, 1974 (Glausiidae) with Montipora foliacea in southeastern India (Sebastian and Pillai, 1974); (4) Xarifia temnura Humes and Ho, 1968 (Xarifiidac) with Montipora sinensis Bernard in Madagascar (Humes and Ho, 1968b).

This paper deals with four new copepods and one previously described species, all representing first records of copepods from the coral genus Montipora in the Pacific Ocean.

The copepods were collected by the author during the Alpha Helix East Asian Bioluminescence Expedition, which was supported by the National Science Foundation of the United States under grants OFS 7401830 and OFS 7402888 to the Scripps Institution of Oceanography and grant BMS 7423242 to the University of California, Santa Barbara. The study of the copepods was aided by NSF grant DEB 77-11879.

The corals were isolated in plastic bags or pails of sea water immediately after collection in the field. A small amount of 95 per cent ethyl alcohol was added to each container sufficient to make approximately a 5 per cent solution. The corals were allowed to remain in this for an hour or longer. They were then vigorously

Publ. Seto Mar. Biol. Lab., XXIV (4/6), 387-407, 1978.

(Article 25) 
and thoroughly washed by strong agitation. The water was then passed through a fine net $(120$ holes per $2.5 \mathrm{~cm})$ and the copepods were picked from the sediment retained.

I thank Dr. John W. Wells, Department of Geological Sciences, Cornell University, for the identification of the corals. I also express my thanks to Mr. Thomas Forhan who collected some of the coral hosts during SCUBA diving.

All figures have been drawn with the aid of a camera lucida. The letter after the explanation of each figure refers to the scale at which it was drawn. The abbreviations used are: $A_{1}=$ first antenna, $A_{2}=$ second antenna, $L=$ labrum, $P=$ paragnath, $\mathrm{MXPD}=$ maxilliped, and $\mathrm{P}_{1}=\operatorname{leg} 1$.

\section{Lichomolgidae Kossmann, 1877}

\section{Allopodion n. gen.}

Diagnosis.--Lichomolgidae. Body elongate. Urosome 5-segmented. Caudal ramus with six setae. Rostrum elongate with rounded posteroventral margin. First antenna 7-segmented. Second antenna 4-segmented with one terminal claw.

Labrum with two posteroventral lobes. Mandible having on convex edge a long proximally directed process followed by a striated fringe and a row of small spines. Concave margin deeply indented and bearing two lobes with marginal spinules. Lash moderately long. Paragnath a small lobe. First maxilla with three setae. Second maxilla 2-segmented. Maxilliped 3-segmented.

Legs 1-4 with 3-segmented rami except for absence of endopod in legs 3 and 4. Third endopod segment of leg 2 with I, II, 2. Third exopod segment of leg 3 with I, 5 and that of $\operatorname{leg} 4$ with $I, 4$; next to outermost seta on these segments broad, finely plumose, and shorter than adjacent setae.

Leg 5 with free segment bearing two terminal setae.

Other features as in species below.

Associated with scleractinian corals.

Gender neuter.

Type-species.-Allopodion mirum n. sp.

Etymology.-The generic name is a combination of the Greek words allos=other or strange, and podion=little foot, referring to the several unusual features in legs 1-4.

\section{Allopodion mirum n. sp. \\ (figs. 1a-i, 2a-j, 3a-c)}

Type material. -4 q $q$ from fragments of one colony of the scleractinian coral Montipora sp. cf. M. undata Bernard, in $10 \mathrm{~m}$, Poelau Parang, eastern Ceram, $3^{\circ} 17^{\prime} 00^{\prime \prime} \mathrm{S}$, $130^{\circ} 44^{\prime} 48^{\prime \prime} \mathrm{E}, 23$ May 1975. Holotype and one paratype deposited in the National Museum of Natural History, Smithsonian Institution, Washington, D.C.; the remain- 
ing paratypes (dissected) in the collection of the author.

Female-Body (figs. 1a, 1b) with pronounced flexure in urosome in preserved specimens. Part of urosome concealed by prosome in dorsal view. Segment of leg 1 indistinctly delimited dorsally from head. Segments carrying legs 2-5 with dorsal

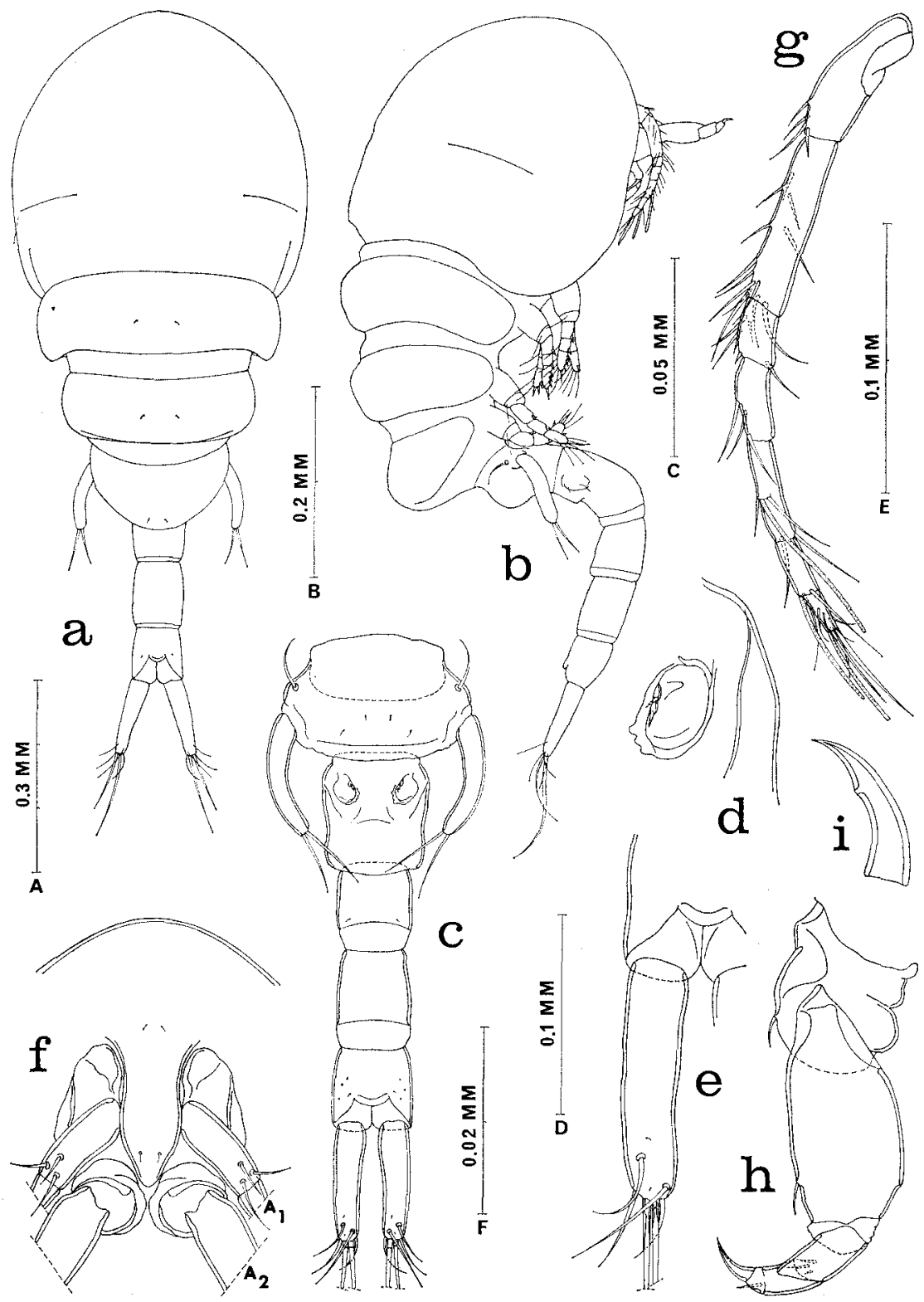

Fig. 1. Allopodion mirum n. gen., n. sp., female. a, dorsal (A); b, lateral (A); c, urosome, dorsal (B); d, genital area, dorsal (C); e, caudal ramus, dorsal (D); $f$, rostrum, ventral (D); $g$, first antenna, ventral $(E) ; h$, second antenna, antero-inner $(E)$; $i$, claw of second antenna, posterior $(\mathbf{F})$. 


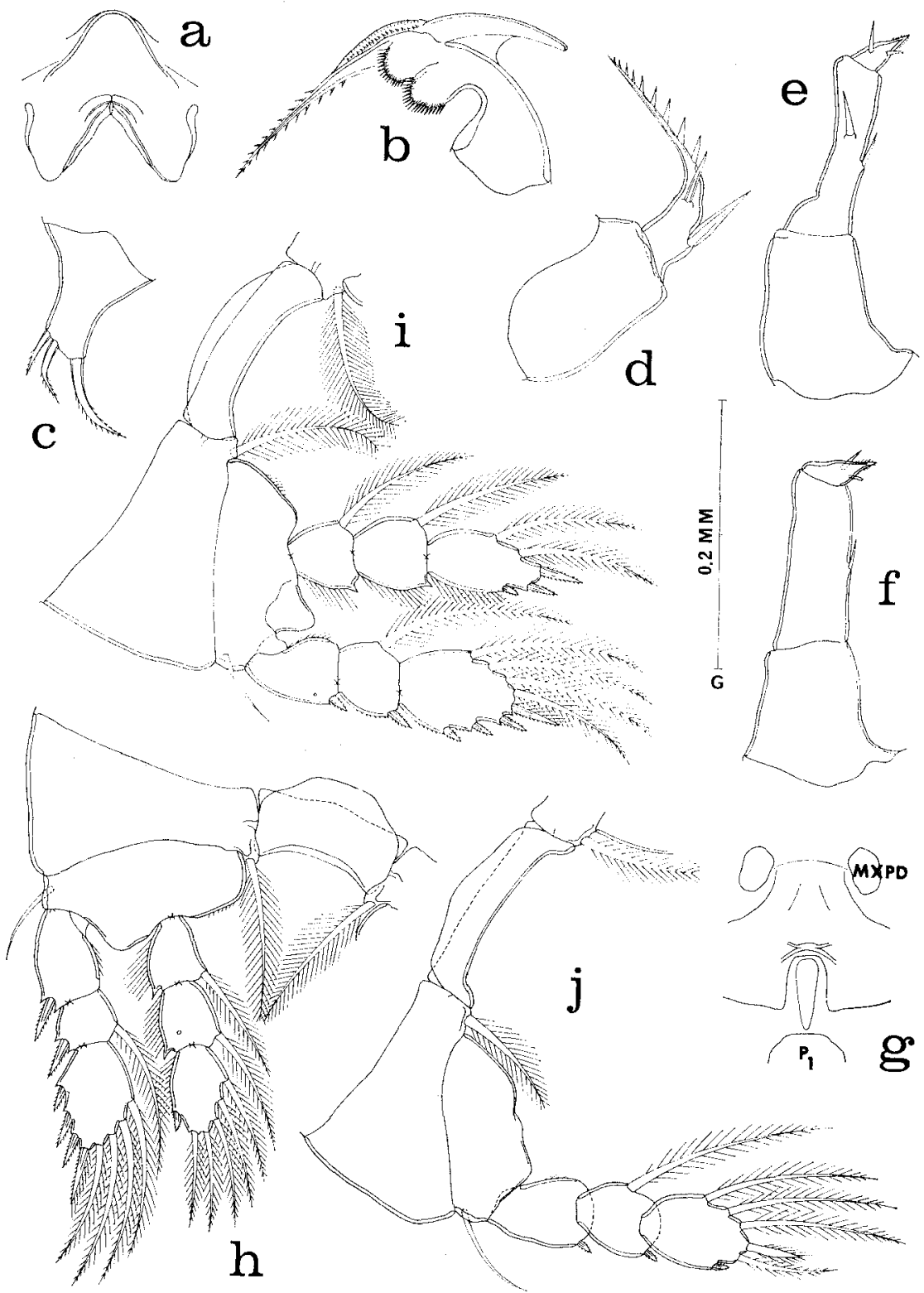

Fig. 2. Allopodion mirum n. gen., n. sp., female. a, labrum, ventral (D); b, mandible, posterior $(\mathrm{C})$; c, first maxilla, posterior $(\mathrm{C})$; d, second maxilla, posterior $(\mathrm{C})$; e, maxilliped, antero-inner $(\mathrm{C})$; f, maxilliped, postero-outer $(\mathrm{C}) ; \mathrm{g}$, area between maxillipeds and first pair of legs, ventral $(\mathrm{G}) ; \mathrm{h}$, leg 1 and intercoxal plate, anterior $(\mathrm{E}) ; \mathrm{i}, \mathrm{leg} 2$ and intercoxal plate, posterior $(\mathbf{E}) ; \mathrm{j}$, leg 3 and intercoxal plate, anterior $(\mathrm{E})$. 
hump, particularly segment bearing leg 5. Ratio of length to width of prosome $1.76: 1$. Ratio of length of prosome to that of urosome 1.21:1 (length of urosome estimated in extended condition).

Segment of leg 5 (fig. 1c) $117 \times 190 \mu \mathrm{m}$. Genital segment $122 \times 104 \mu \mathrm{m}$, nearly rectangular in dorsal view. Genital areas situated dorsolaterally in anterior half of segment. Each area (fig. 1d) bearing two minute indistinct spines about $5 \mu \mathrm{m}$ long. Three postgenital segments from anterior to posterior $86 \times 75 \mu \mathrm{m}, 99 \times 73 \mu \mathrm{m}$, and $81 \times 75 \mu \mathrm{m}$. Posteroventral margin of anal segment smooth.

Caudal ramus (fig. 1e) elongate, $117 \times 28 \mu \mathrm{m}$, ratio of length to width $4.18: 1$. Outer lateral seta $44 \mu \mathrm{m}$, dorsal seta $55 \mu \mathrm{m}$, outermost terminal seta $45 \mu \mathrm{m}$, innermost terminal seta $31 \mu \mathrm{m}$, and two median terminal setac $104 \mu \mathrm{m}$ (outer) and $146 \mu \mathrm{m}$ (inner). All setae smooth.

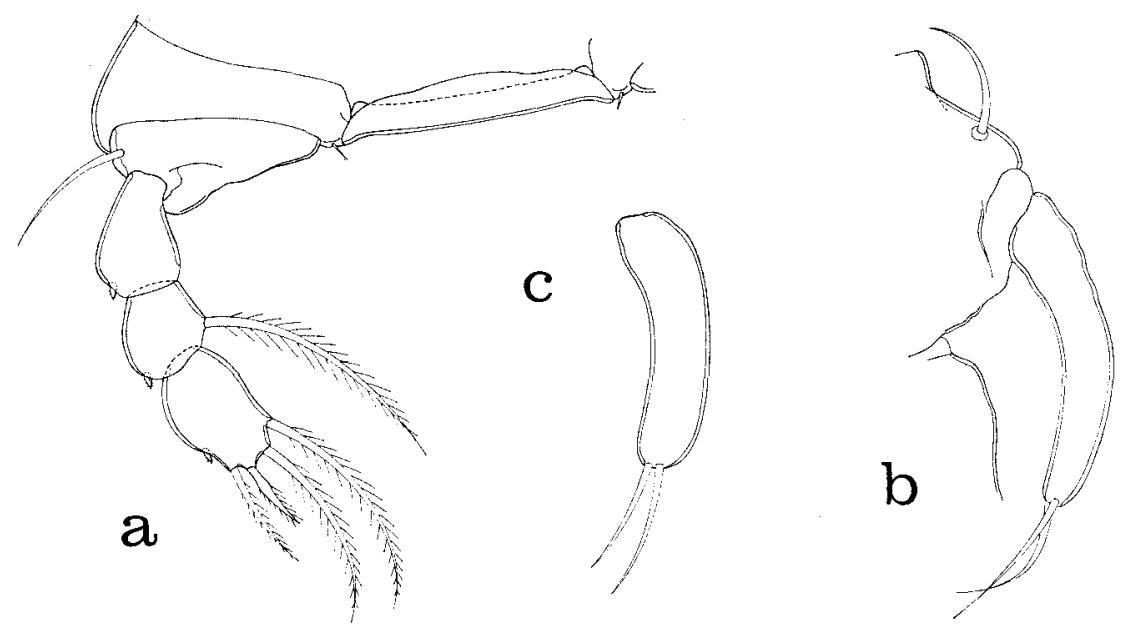

Fig. 3. Allopodion mirum n. gen., n. sp., female. a, leg 4 and intercoxal plate, posterior (E); b, leg 5, dorsal (D); c, free segment of leg 5, lateral (D).

Body surface with very few sensilla.

Egg sac not seen.

Rostrum (fig. If) elongate with rounded posteroventral tip.

First antenna (fig. 1g) $223 \mu \mathrm{m}$ long. Lengths of seven segments (measured along their posterior margins): 22 (52 $\mathrm{m}$ along anterior margin), 60, 18, 26, 33, 20 , and $14 \mu \mathrm{m}$ respectively. Formula for armature: $4,13,6,3,4+1$ aesthete $2+1$ aesthete, and $7+1$ aesthete. All setae naked.

Second antenna (fig. 1h) 4-segmented and $133 \mu \mathrm{m}$ long. Formula: 1, 1, 3, and one claw and one steule. Setae on third segment weak. Fourth segment small, 17 $\mu \mathrm{m}$ along outer edge, $10 \mu \mathrm{m}$ along inner edge, and $11 \mu \mathrm{m}$ wide. Claw (fig. li) smoothly recurved, $17 \mu \mathrm{m}$.

Labrum (fig. 2a) with two moderately slender posteroventral lobes. Mandible (fig. 2b) with concave edge having a long proximally directed digitiform process followed by a minutely striated fringe and row of very small spines. Concave margin 
distal to deep indentation with two lobes armed with marginal spinules. Lash moderately long and barbed. Paragnath a small smooth lobe. First maxilla (fig. 2c) with three delicately barbed setac. Second maxilla (fig. 2d) 2-segmented, with rather slender unornamented proximal segment. Second segment bearing two smooth equal setae, one seta with narrow hyaline lamellae; segment produced to form a lash with row of widely spaced spines. Maxilliped (figs. 2e, 2f) 3-segmented. First segment unarmed. Second segment with two naked setae. Small third segment with two small naked setae, one with a blunt tip; distal end of segment spiniform and minutely barbed.

Ventral area between maxillipeds and first pair of legs (fig. $2 \mathrm{~g}$ ) not produced ventrally.

Legs 1-4 (figs. 2h, 2i, 2j, 3a) with 3-segmented rami except for absence of endopods in legs 3 and 4 . Formula for legs $1-4$ as follows (Roman numerals representing spines, Arabic numerals setae):

\begin{tabular}{|c|c|c|c|c|c|c|c|c|}
\hline$P_{1}$ & coxa & $0-1$ & basis & $1-0$ & $\begin{array}{l}\exp \\
\text { enp }\end{array}$ & $\begin{array}{l}\mathrm{I}-0 \\
0-1\end{array}$ & $\begin{array}{l}\mathrm{I}-1 ; \\
0-1 ;\end{array}$ & $\begin{array}{l}\text { III, I, } 4 \\
\text { I, } 5\end{array}$ \\
\hline $\mathrm{P}_{2}$ & coxa & $0-1$ & basis & $1-0$ & $\exp$ & $\mathrm{I}-0$ & I-1; & III, I, 4 \\
\hline & & & & & enp & $0-1$; & $0-1$; & $\mathrm{I}, \mathrm{II}, 2$ \\
\hline $\mathrm{P}_{3}$ & coxa & $0-1$ & basis & $1-0$ & $\begin{array}{l}\text { exp } \\
\text { enp }\end{array}$ & $\begin{array}{l}\mathrm{I}-0 ; \\
\text { absent }\end{array}$ & I-1; & $\mathrm{I}, 5$ \\
\hline $\mathrm{P}_{4}$ & coxa & $0-1$ & basis & $1-0$ & $\begin{array}{l}\text { exp } \\
\text { enp }\end{array}$ & $\begin{array}{l}\mathrm{I}-0 ; \\
\text { absent }\end{array}$ & I-1; & $\mathrm{I}, 4$ \\
\hline
\end{tabular}

Inner coxal seta in legs $1-3$ long and plumose but in leg 4 minute, $6 \mu \mathrm{m}$, and smooth. Third segment of endopod of leg 2 with armature reduced to I, II, 2, instead of I, II, 3 as in many other lichomolgids. Third segment of exopod in leg 3 and leg 4 with only one spine and next to outermost seta broad, finely plumose and shorter than adjacent setae.

Leg 5 (fig. 3b) with elongate unornamented free segment $101 \times 23 \mu \mathrm{m}$, ratio $4.39: 1$, this segment appearing narrower in dorsal view than in flat lateral view (fig. 3c). Two terminal setae $41 \mu \mathrm{m}$ and $44 \mu \mathrm{m}$. Dorsal seta near insertion of free segment $47 \mu \mathrm{m}$. All three setae smooth.

Leg 6 represented by two minute spines on genital area (fig. 1d).

Living specimens in transmitted light pale gray, eye red.

Male.-Unknown.

Remarks.-The following three features, taken in combination, serve to distinguish Allopodion from all other genera in the family Lichomolgidae: (1) legs 3 and 4 with 3-segmented exopods but lacking endopods, (2) third segment of exopod in legs 3 and 4 with only one spine, and (3) convex side of mandible with a large proximally directed process.

Kawanolus n. gen.

Diagnosis.-Lichomolgidae. Body elongate. Urosome 5-segmented. Caudal 
ramus with six setae. Rostrum with rounded posteroventral margin. First antenna 7-segmented. Second antenna 4-segmented, with one terminal claw.

Labrum with two posteroventral lobes. Mandible having on convex edge a large proximally directed process followed by a row of minute spines and a small pectinate fringe; comblike row of spinules near origin of process. Concave margin deeply indented and bearing two lobes with marginal spinules. Lash moderately long. Paragnath a small lobe. First maxilla with four setae. Second maxilla 2segmented. Maxilliped 3-segmented. Ventral area in front of intercoxal plate of leg 1 without a sclerite.

Leg 1-4 with 3-segmented rami except for 2-segmented endopod in leg 3 and absence of endopod in leg 4 . Inner coxal seta of leg 4 absent. Third exopod segments of legs 2, 3, and 4 armed with II, I, 5; I, I, 4; and I, 4 respectively. Endopod of leg 3 with $0-0 ; 2$.

Leg 5 with free segment bearing two terminal setae.

Other features as in species below.

Associated with scleractinian corals.

Gender masculine.

Type species.-Kawanolus parangensis $\mathrm{n} . \mathrm{sp}$.

Etymology.- The generic name is a combination of the Malay word kawan, meaning a companion, and the Latin diminutive suffix -olus, alluding to the association with corals.

\section{Kawanolus parangensis n. sp.}

(figs. 4a-i, 5a-k, 6a-d)

Type material.--7 우우 from fragments of one colony of the scleractinian coral Montipora sp. $f f$. M. undata Bernard in $10 \mathrm{~m}$, Poelau Parang, eastern Ceram, $3^{\circ} 17^{\prime} 00^{\prime \prime} \mathrm{S}$, $130^{\circ} 44^{\prime} 48^{\prime \prime} \mathrm{E}, 23$ May 1975. (Allopodion mirum was also recovered from this colony of coral, as noted above.) Holotype and 3 paratypes deposited in the National Museum of Natural History, Smithsonian Institution, Washington, D.C.; the remaining paratypes (dissected) in the collection of the author.

Female.-Body (figs. 4a, 4b) elongate and slender. External segmentation in prosome weak. Urosome recurved in preserved specimens. Length (not including setae on caudal rami) $1.08 \mathrm{~mm}(0.92-1.13 \mathrm{~mm})$, greatest width $0.29 \mathrm{~mm}(0.28-0.30$ $\mathrm{mm})$, and dorsoventral thickness in prosome $0.29 \mathrm{~mm}(0.25-0.31 \mathrm{~mm})$, based on 7 specimens in lactic acid. Ratio of length to width of prosome 2.77:1. Ratio of length of prosome to that of recurved urosome 2.92:1.

Segment of leg 5 (fig. 4c) $60 \times 153 \mu \mathrm{m}$. Genital segment $127 \times 135 \mu \mathrm{m}$, a little wider than long, broadest in its anterior half and smoothly narrowed posteriorly. Genital areas located dorsolaterally near middle of segment. Each area (fig. 4d) with two minute spines approximately $4 \mu \mathrm{m}$ long. Three postgenital segments from anterior to posterior $44 \times 81 \mu \mathrm{m}, 42 \times 78 \mu \mathrm{m}$, and $55 \times 91 \mu \mathrm{m}$. Posteroventral margin of anal segment smooth. 
Caudal ramus (fig. 4e) elongate and unornamented, $122 \times 36 \mu \mathrm{m}$, ratio of length to width $3.39: 1$. Outer lateral seta $38 \mu \mathrm{m}$, dorsal seta $44 \mu \mathrm{m}$, outermost terminal seta $44 \mu \mathrm{m}$, innermost terminal seta $66 \mu \mathrm{m}$, and two median terminal setae $138 \mu \mathrm{m}$ (outer) and $190 \mu \mathrm{m}$ (inner). All setae smooth.

Body surface with very few sensilla.

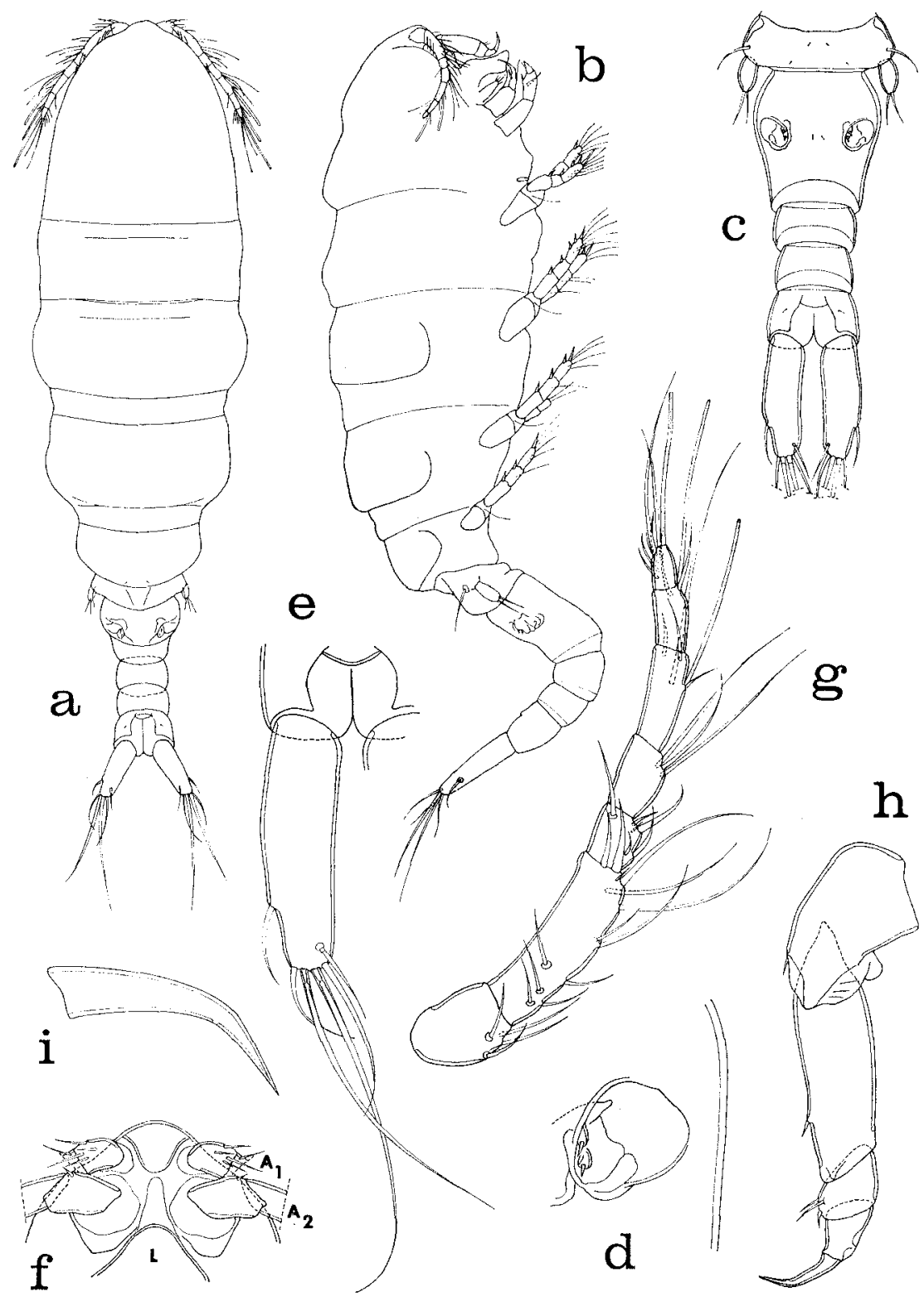

Fig. 4. Kawanolus parangensis n. gen., n. sp., female. a, dorsal (A); b, lateral (A); c, uosome, dorsal (B); d, genital area, dorsal (C); e, caudal ramus, dorsal (D); $f$, rostrum, ventral $(G)$; g, first antenna, anterodorsal $(E) ; h$, second antenna, inner (E); i, claw of second antenna, inner (F). 

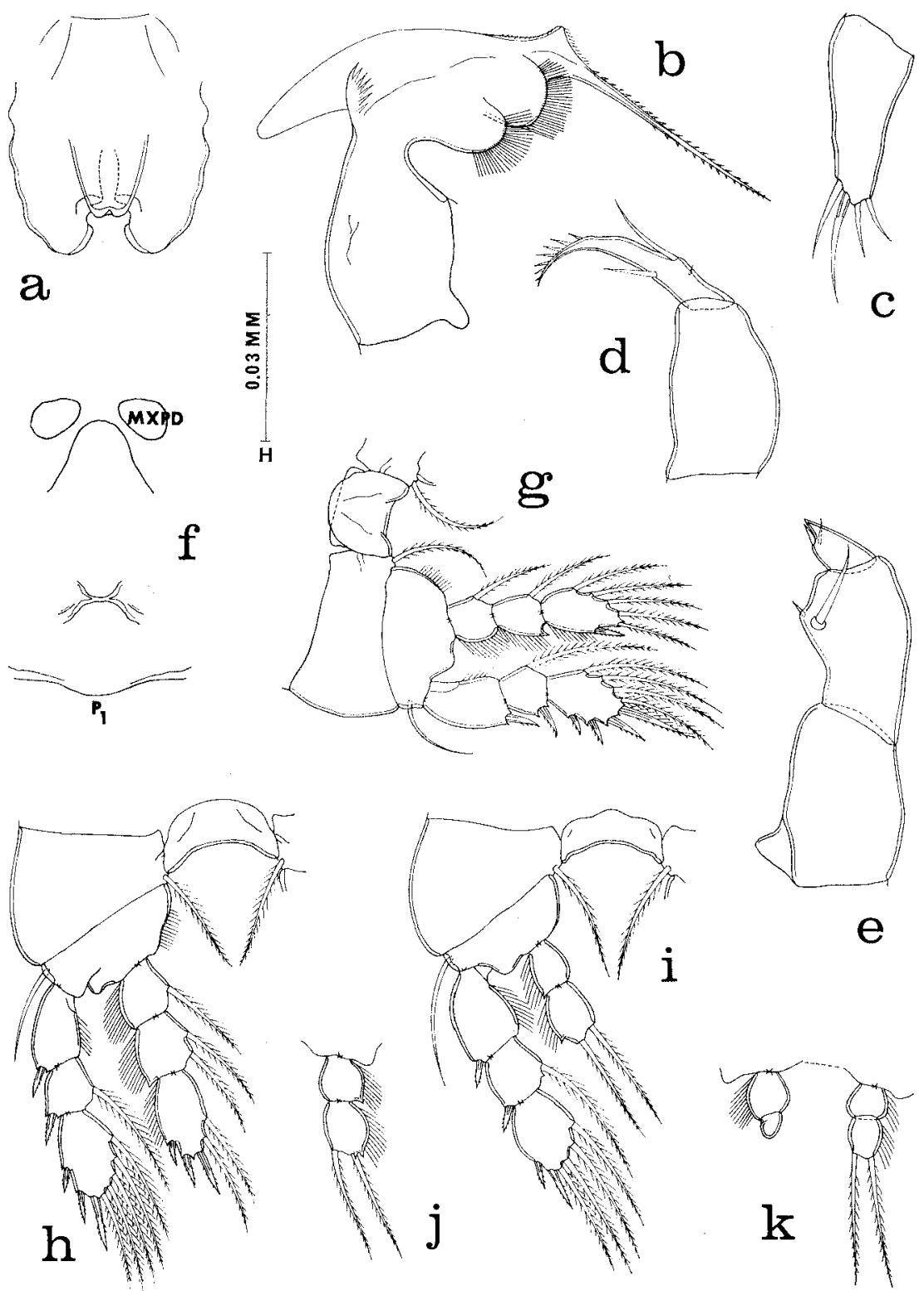

Fig. 5. Kawanolus parangensis n. gen., n. sp., female. a, labrum, ventral (E); b, mandible, posterior $(\mathbf{H})$; c, first maxilla, ventral $(\mathbf{H})$; d, second maxilla, anterior (C); e, maxilliped, inner (C); f, area between maxillipeds and first pair of legs, ventral (D); g, leg 1 and intercoxal plate, anterior (D); h, leg 2 and intercoxal plate, anterior (D); $\mathrm{i}$, leg 3 and intercoxal plate, anterior (D); $j$, endopod of leg 3 , anterior (D); $k$, endopods of leg 3 , posterior (D). 
Egg sac not seen.

Rostrum (fig. 4f) small with rounded posteroventral margin.

First antenna (fig. 4g) $200 \mu \mathrm{m}$ long. Lengths of seven segments (measured along their posterior margins) 21 (34 $\mu \mathrm{m}$ along anterior margin), 57, 19, 26, 31, 19, and $15 \mu \mathrm{m}$ respectively. Formula for armature: 4, 13, 6, 3, 4+1 aesthete, $2+1$ aesthete, and $7+1$ aesthete. All setae naked.

Second antenna (fig. 4h) 4-segmented and $151 \mu \mathrm{m}$ long without claw. Formula: 1, 1, 3, and one claw. Fourth segment small, greatest dimensions about $20 \times 16.5$ $\mu \mathrm{m}$. Claw (fig. 4i) $27 \mu \mathrm{m}$ and slightly angular. All setae naked.

Labrum (fig. 5a) with two small posteroventral lobes; median area between lobes raised ventrally. Mandible (fig. 5b) with convex edge having large hyaline proximally directed process and distally a row of minute spines and an inconspicuous pectinate fringe. Comblike row of several spinules near origin of hyaline process.
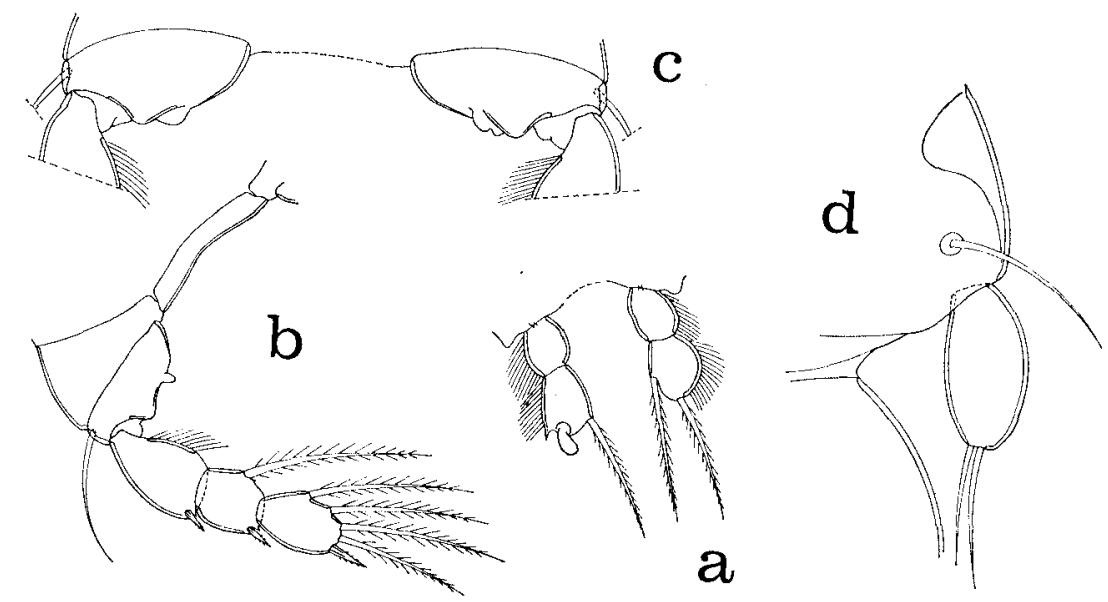

Fig. 6. Kawanolus parangensis n. gen., n. sp., female. a, endopods of leg 3, anterior (D); b, leg 4 and intercoxal plate, anterior (D); c, right and left basis of leg 4, anterior (E); d, leg 5, dorsal (C).

Concave margin distal to deep indentation with two lobes carrying long marginal spinules. Lash moderately long and barbed. Paragnath a small smooth lobe. First maxilla (fig. 5c) with four smooth setae. Second maxilla (fig. 5d) 2-segmented. First segment moderately slender and unarmed. Second segment slender and elongate, bearing a minute setule and two smooth setae; lash short with relatively few slender spines. Maxilliped (fig. 5e) 3-segmented. First segment unarmed. Second segment with two very unequal naked setae. Small third segment with two small naked setae and terminating in a short smooth spiniform process.

Ventral area between maxillipeds and first pair of legs (fig. 5f) lacking median sclerite in front of first intercoxal plate seen in most lichomolgids. This area slightly raised ventrally (fig. $4 \mathrm{~b}$ ).

Legs 1-4 (figs. 5g, 5h, 5i, 6b) with 3-segmented rami except for 2-segmented 
endopod in leg 3 and virtual absence of endopod in leg 4. Formula for legs 1-4 as follows (Roman numerals representing spines, Arabic numerals indicating setae):

\begin{tabular}{lllllllll}
$\mathrm{P}_{1}$ & coxa & $0-1$ & basis & $1-0$ & $\exp$ & $\mathrm{I}-0 ;$ & $\mathrm{I}-1 ;$ & $\mathrm{III}, \mathrm{I}, 4$ \\
& & & & & $\operatorname{enp}$ & $0-1 ;$ & $0-1 ;$ & $\mathrm{I}, 5$ \\
$\mathrm{P}_{2}$ & coxa & $0-1$ & basis & $1-0$ & $\exp$ & $\mathrm{I}-0 ;$ & $\mathrm{I}-1 ;$ & $\mathrm{II}, \mathrm{I}, 5$ \\
& & & & & $\operatorname{enp}$ & $0-1 ;$ & $0-2 ;$ & $\mathrm{I}, \mathrm{II}, 2$ \\
$\mathrm{P}_{3}$ & $\operatorname{coxa}$ & $0-1$ & basis & $1-0$ & $\exp$ & $\mathrm{I}-0 ;$ & $\mathrm{I}-1 ;$ & $\mathrm{I}, \mathrm{I}, 4$ \\
& & & & & $\operatorname{enp}$ & $0-0 ;$ & 2 & \\
$\mathrm{P}_{4}$ & $\operatorname{coxa}$ & $0-0$ & basis & \multirow{2}{*}{$1-0$} & $\exp$ & $\mathrm{I}-0 ;$ & $\mathrm{I}-1 ;$ & $\mathrm{I}, 4$
\end{tabular}

Endopod of leg 3 showing considerable variation in shape and ornamentation (figs. $5 \mathrm{j}, 5 \mathrm{k}, 6 \mathrm{a}$ ). Endopod of leg 4 absent but its position perhaps indicated by a small rounded process (fig. 6b) or a slight lobe (fig. 6c). Inner coxal seta of leg 4 absent.

Leg 5 (fig. 6d) with oval unornamented free segment $33 \times 16.5 \mu \mathrm{m}$, ratio $2: 1$. Two terminal setae $20 \mu \mathrm{m}$ and $28 \mu \mathrm{m}$. Dorsal seta near free segment $40 \mu \mathrm{m}$. All three setae naked.

Leg 6 represented by two minute spines on genital area (fig. 4d).

Living specimens in transmitted light pale gray, eye red.

Male-Unknown.

Elymology.-The specific name is a combination of Parang, the name of the island which is the type locality, and the Latin suffix -ensis, living in or inhabitant of.

Remarks.--In addition to the new genus there are three lichomolgid genera in which leg 4 has a well developed 3-segmented exopod but lacks an endopod. All genera are associates of scleractinian corals. They differ from Kawanolus as follows:

Mycoxynus Humes, 1973,---second antenna 3-segmented, endopod of leg 3 absent.

Rakotoa Humes and Stock, 1972, - endopod of leg 3 three-segmented, inner coxal seta of leg 4 present.

Ravahina Humes and Ho, 1968b,--endopod of leg 3 absent, mandible without a posteriorly directed process.

\section{Haplomolgus Humes and Ho, 1968a}

\section{Haplomolgus montiporae Humes and Ho, 1968a}

Specimens collected. 160 우, $\mathbf{8 6}$ ô for from Montipora compressa (Esper), in $2 \mathrm{~m}$,

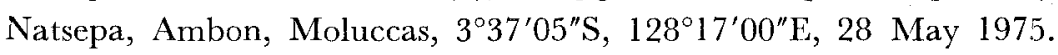

Remarks.-The Moluccan specimens were compared with paratypes of $H$. montiporae from Madagascar. No significant differences were found between the two groups of specimens collected approximately 9,000 kms apart. Montipora compressa is a new host for Haplomolgus montiporae. 


\section{Haplomolgus subdeficiens n. sp.}

$$
\text { (figs. 7a-k, 8a-h, 9a-c) }
$$

Type material. -2 우 from fragments of one colony of the scleractinian coral Montipora sp. cf. M. undata Bernard, in $10 \mathrm{~m}$, Poelau Parang, eastern Ceram, $3^{\circ} 17^{\prime} 00^{\prime \prime} \mathrm{S}$, $130^{\circ} 44^{\prime} 48^{\prime \prime} \mathrm{E}, 23$ May 1975. (Allopodion mirum and Kawanolus parangensis were also recovered from this colony of coral, as noted above.) Holotype deposited in the National Museum of Natural History, Smithsonian Institution, Washington, D.C.; one paratype (dissected) in the collection of the author.

Femalc.-Body (figs. 7a, 7b) elongate and slender. Urosome recurved in preserved specimens. Length (excluding setae on caudal rami) and width of two specimens in lactic acid: $1.08 \times 0.28 \mathrm{~mm}$ and $0.98 \times 0.28 \mathrm{~mm}$. Dorsoventral thickness in prosome $0.28 \mathrm{~mm}$. Ratio of length to width of prosome $2.53: 1$. Ratio of length of prosome to that of urosome (length of urosome estimated in extended condition) $1.70: 1$.

Segment of leg 5 (fig. 7c) $73 \times 172 \mu \mathrm{m}$. Genital segment $91 \times 117 \mu \mathrm{m}$, a little wider than long, broadest in middle. Genital areas situated dorsolaterally in anterior half of segment. Each area (fig. 7d) with two minute setae $3 \mu \mathrm{m}$ and $2 \mu \mathrm{m}$. Three postgenital segments from anterior to posterior $73 \times 74 \mu \mathrm{m}, 88 \times 83 \mu \mathrm{m}$, and $60 \times 81$ $\mu \mathrm{m}$. Posteroventral margin of anal segment smooth.

Caudal ramus (fig. 7e) elongate, $70 \times 26 \mu \mathrm{m}$, ratio of length to width 2.69:1. Outer lateral seta $44 \mu \mathrm{m}$, dorsal seta $31 \mu \mathrm{m}$, outermost terminal seta $57 \mu \mathrm{m}$, innermost terminal seta $65 \mu \mathrm{m}$, and two median terminal setae $83 \mu \mathrm{m}$ (outer) and $104 \mu \mathrm{m}$ (inner). All setae smooth.

Body surface with very few sensilla.

Egg sac not seen.

Rostrum (fig. 7f) small with posteroventral margin rounded in lateral view (fig. $7 \mathrm{~g})$.

First antenna (fig. $7 \mathrm{~h}$ ) $183 \mu \mathrm{m}$ long. Lengths of seven segments (measured along their posterior margins) 8 (33 $\mu \mathrm{m}$ along anterior margin), 48, 15, 20, 31, 21, and $15 \mu \mathrm{m}$ respectively. Formula for armature: $4,13,6,3,4+1$ aesthete, $2+1$ aesthete, and $7+1$ aesthete. All setae naked.

Second antenna (fig. 7i) 4-segmented and $133 \mu \mathrm{m}$ long. Formula: 1, 1, 3, and one claw. Small setule near base of claw. Claw (fig. 7j) $26 \mu \mathrm{m}$ and evenly recurved. All setae naked.

Labrum (fig. 7k) with two short broad truncated lobes. Mandible (fig. 8a) with convex edge having a large hyaline proximally directed process and distally a delicate striated fringe and a row of small spines. Concave margin distal to indentation with two lobes carrying two rows of spinules. Lash moderately long and distally barbed. Paragnath (fig. 7k) a small lobe with a few minute distal spines. First maxilla (fig. 8b) with three finely barbed setae. Second maxilla (fig. 8c) 2segmented. First segment unornamented. Second segment elongate bearing two setae, one short and smooth, other longer with narrow hyaline lamellae. Lash 
relatively short with sparsely arranged slender spines. Maxilliped (fig. 8d) 3-segmented. First segment unarmed. Second segment with two very unequal smooth setae. Third segment, flattened as in Allopodion, with a smooth acuminate tip and bearing two naked setae.
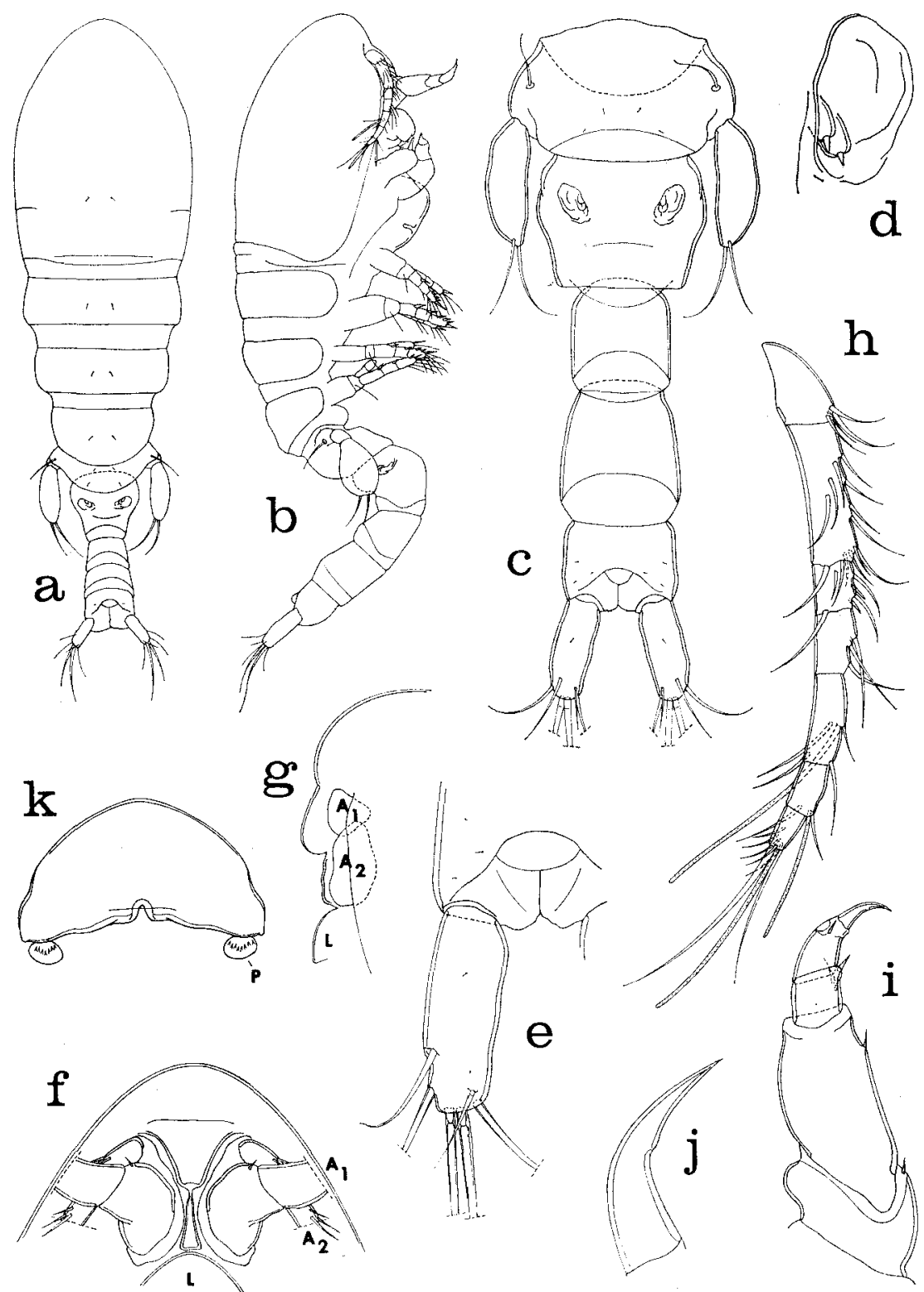

Fig. 7. Haplomolgus subdeficiens n. sp., female. a, dorsal (A); b, lateral (A); c, urosome, dorsal $(G)$; d, genital area, dorsal $(H)$; e, caudal ramus, dorsal (E); f, rostrum, ventral $(G) ; g$, rostrum, lateral $(G)$; $h$, first antenna, dorsal $(E) ; i$, second antenna, anterior $(\mathbf{E}) ; j$, claw of second antenna, anterior $(F) ; k$, labrum and paragnaths, ventral $(\mathrm{E})$. 
Ventral area between maxillipeds and first pair of legs (fig. 8e) with a very slender elongate median sclerite anterior to leg 1 and produced ventrally (fig. $7 \mathrm{~b}$ ).

Legs 1-4 (figs. 8f, 8g, 8h, 9b) with 3-segmented rami except for 2-segmented endopod in leg 4. Formula for legs $1-4$ as follows (Roman numerals indicating

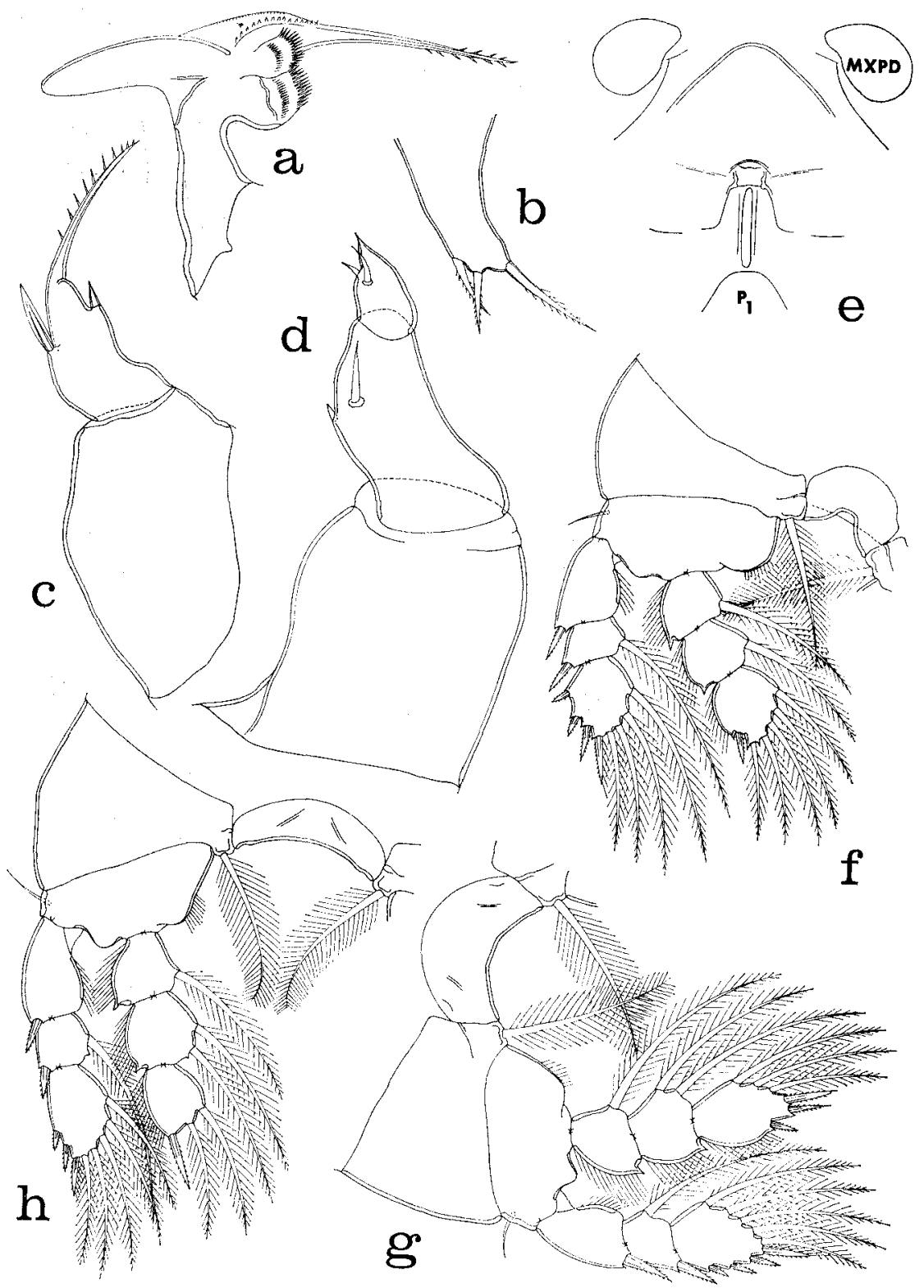

Fig. 8. Haplomolgus subdeficiens $\mathbf{n}$. sp., female. a, mandible, posterior $(\mathbf{H})$; b, first maxilla, ventral $(\mathbf{H})$; c, second maxilla, posterior $(\mathbf{H})$; d, maxilliped, inner $(\mathbf{H})$; e, area between maxillipeds and first pair of legs, ventral (D); f, leg 1 and intercoxal plate, anterior $(\mathrm{E}) ; \mathrm{g}, \operatorname{leg} 2$ and intercoxal plate, anterior $(\mathrm{E}) ; \mathrm{h}, \mathrm{leg} 3$ and intercoxal plate, anterior (E). 
spines, Arabic numerals representing setae):

\begin{tabular}{lllllllll}
$\mathrm{P}_{1}$ & coxa & $0-1$ & basis & $1-0$ & $\exp$ & $\mathrm{I}-0 ;$ & $\mathrm{I}-1 ;$ & $\mathrm{III}, \mathrm{I}, 4$ \\
& & & & & $\operatorname{enp}$ & $0-1 ;$ & $0-1 ;$ & $\mathrm{I}, 5$ \\
$\mathrm{P}_{2}$ & $\operatorname{coxa}$ & $0-1$ & basis & $1-0$ & $\exp$ & $\mathrm{I}-0 ;$ & $\mathrm{I}-1 ;$ & $\mathrm{III}, \mathrm{I}, 5$ \\
& & & & & $\operatorname{enp}$ & $0-1 ;$ & $0-2 ;$ & $\mathrm{I}, \mathrm{II}, 3$ \\
$\mathrm{P}_{3}$ & $\operatorname{coxa}$ & $0-1$ & basis & $1-0$ & $\exp$ & $\mathrm{I}-0 ;$ & $\mathrm{I}-1 ;$ & $\mathrm{II}, \mathrm{I}, 5$ \\
& & & & & $\operatorname{enp}$ & $0-1 ;$ & $0-2 ;$ & $\mathrm{I}, 2$ (or 2) \\
$\mathrm{P}_{4}$ & \multirow{2}{*}{ coxa } & $0-1$ & basis & \multirow{2}{*}{$1-0$} & $\exp$ & $\mathrm{I}-0 ;$ & $\mathrm{I}-1 ;$ & $\mathrm{II}, \mathrm{I}, 5$ \\
& & & & & $\operatorname{enp}$ & $0-0 ;$ & 0 &
\end{tabular}

Inner coxal seta long and plumose in legs $1-3$ but minute, $7 \mu \mathrm{m}$, and naked in leg 4. Terminal armature of endopod of leg 3 variable, either I, 2 or 2 (figs. $8 \mathrm{~h}$, 9a). Endopod of leg 4 without spines or setae; outer margin of both segments with row of hairs.
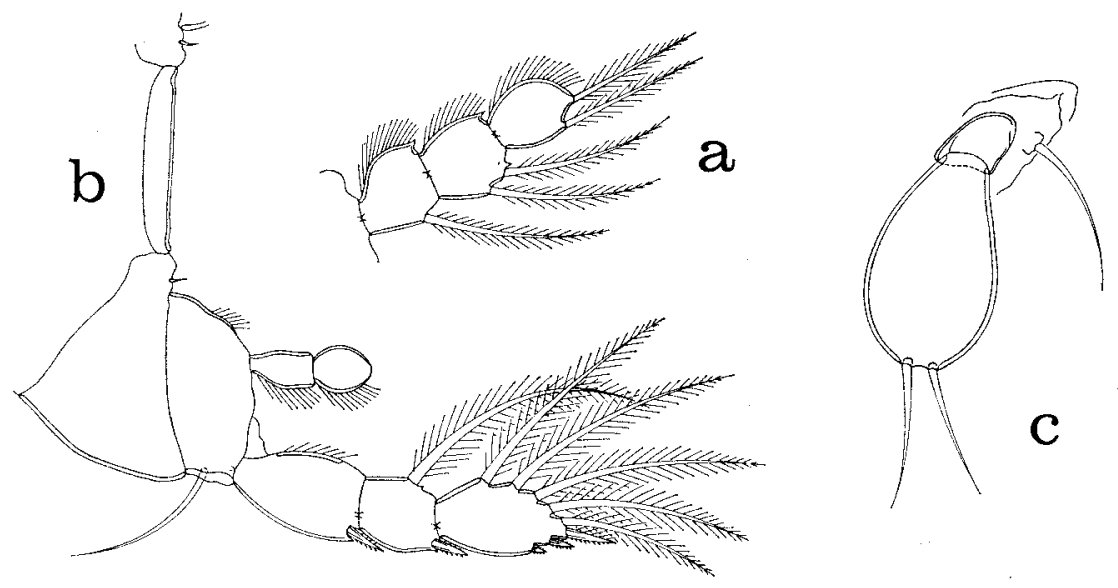

Fig. 9. Haplomolgus subdeficiens n. sp., female. a, endopod of leg 3 , anterior (E); b, leg 4 and intercoxal plate, anterior (E); $\mathrm{c}, \operatorname{leg} 5$, lateral (D).

Leg 5 (fig. 9c) with broad flattened free segment $88 \times 52 \mu \mathrm{m}$ inserted on a surficial sclerotized area that creates an impression of a small proximal segment. Two terminal setae $55 \mu \mathrm{m}$ and $52 \mu \mathrm{m}$. Dorsal seta near insertion of free segment $68 \mu \mathrm{m}$. All setae smooth.

Leg 6 represented by two minute setae on genital area (fig. 7d).

Living specimens in transmitted light pale gray, eye red.

Male.-Unknown.

Etymology.-The specific name subdeficiens, Latin=somewhat failing or lacking, alludes to the reduced armature on the third segment of the endopod of leg 3.

Comparison with Haplomolgus montiporae.-The following features of Haplomolgus subdeficiens serve to distinguish it from the only other species in the genus, Haplomolgus montiporae Humes and Ho, 1968a: (1) 3 setae on the first maxilla (instead of 4); (2) slender spinules on the lash of the second maxilla (instead of dentiform spinules); 
(3) the terminal spine on the third segment of the exopod of leg 1 shorter than the segment (rather than much longer than the segment); (4) the third segment of the endopod of leg 2 and leg 3 not much longer than wide (instead of elongate and slender); (5) the formula for the third segment of the endopod of leg 3 being I, 2 or 2 (rather than II, 2); and (6) the endopod of leg 4 two-segmented (instead of one-segmented or one-segmented with a small hyaline lobe attached to the segment).

\title{
Odontomolgus Humes and Stock, 1972
}

\section{Odontomolgus forhani $\mathrm{n} . \mathrm{sp}$.}

\author{
(figs. 10a-k, 11a-i, 12a-g)
}

Type material.-64 우, 65 of from fragments of a colony of the scleractinian coral Montipora compressa (Esper), in $2 \mathrm{~m}$, Natsepa, Ambon, Moluccas, 3 $37^{\prime} 05^{\prime \prime} \mathrm{S}$, $128^{\circ} 17^{\prime} 00^{\prime \prime} \mathrm{E}, 28$ May 1975. (Haplomolgus montiporae was also recovered from this colony of coral, as noted above.) Holotype $q$, allotype, and 116 paratypes (60 우, 560 o) deposited in the National Museum of Natural History, Smithsonian Institution, Washington, D.C.; the remaining paratypes (dissected) in the collection of the author.

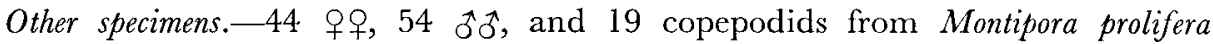
(Brueggemann), in $3 \mathrm{~m}$, southern shore of Goenoeng Api, Banda Islands, $4^{\circ} 32^{\prime} 05^{\prime \prime} \mathrm{S}$, $129^{\circ} 52^{\prime} 30^{\prime \prime} \mathrm{E}, 26$ April 1975.

Female.-Body (fig. 10a) with moderately broad prosome; in lateral view resembling Odontomolgus mundulus Humes, 1974. Length (not including setae on caudal rami) $1.04 \mathrm{~mm}(0.97-1.11 \mathrm{~mm})$ and greatest width $0.38 \mathrm{~mm}(0.32-0.42 \mathrm{~mm})$, based on 10 specimens in lactic acid. Segment of leg 1 indistinctly delimited from head dorsally. Ratio of length to width of prosome 1.88:1. Ratio of length of prosome to that of urosome $2.47: 1$.

Segment of leg 5 (fig. 10b) $55 \times 130 \mu \mathrm{m}$. Genital segment $169 \times 146 \mu \mathrm{m}$, its lateral margins in dorsal view slightly undulating. Genital areas located dorsolaterally near middle of segment. Each area (fig. 10c) with two unequal setae $5 \mu \mathrm{m}$ and $16 \mu \mathrm{m}$ and a small spiniform process. Three postgenital segments from anterior to posterior $49 \times 68 \mu \mathrm{m}, 34 \times 62 \mu \mathrm{m}$, and $65 \times 66 \mu \mathrm{m}$. Posteroventral border of anal segment with row of minute spinules on each side.

Caudal ramus (fig. 10d) elongate, $86 \times 26 \mu \mathrm{m}$, with ratio of length to width 3.30:1. Outer lateral seta $91 \mu \mathrm{m}$, dorsal seta $45 \mu \mathrm{m}$, outermost terminal seta $108 \mu \mathrm{m}$, and innermost terminal seta $145 \mu \mathrm{m}$, all naked. Two long median terminal setae 220 $\mu \mathrm{m}$ (outer) and $330 \mu \mathrm{m}$ (inner), both inserted between small dorsal and ventral flanges and both with strong lateral spinules along their midregions.

Body surface with very few hairs (sensilla) as in figure 10a.

Egg sac unknown.

Rostrum (fig. 10e) weakly developed. First antenna (fig. 10f) $281 \mu \mathrm{m}$ long. Lengths of seven segments (measured along their posterior nonsetiferous margins): 


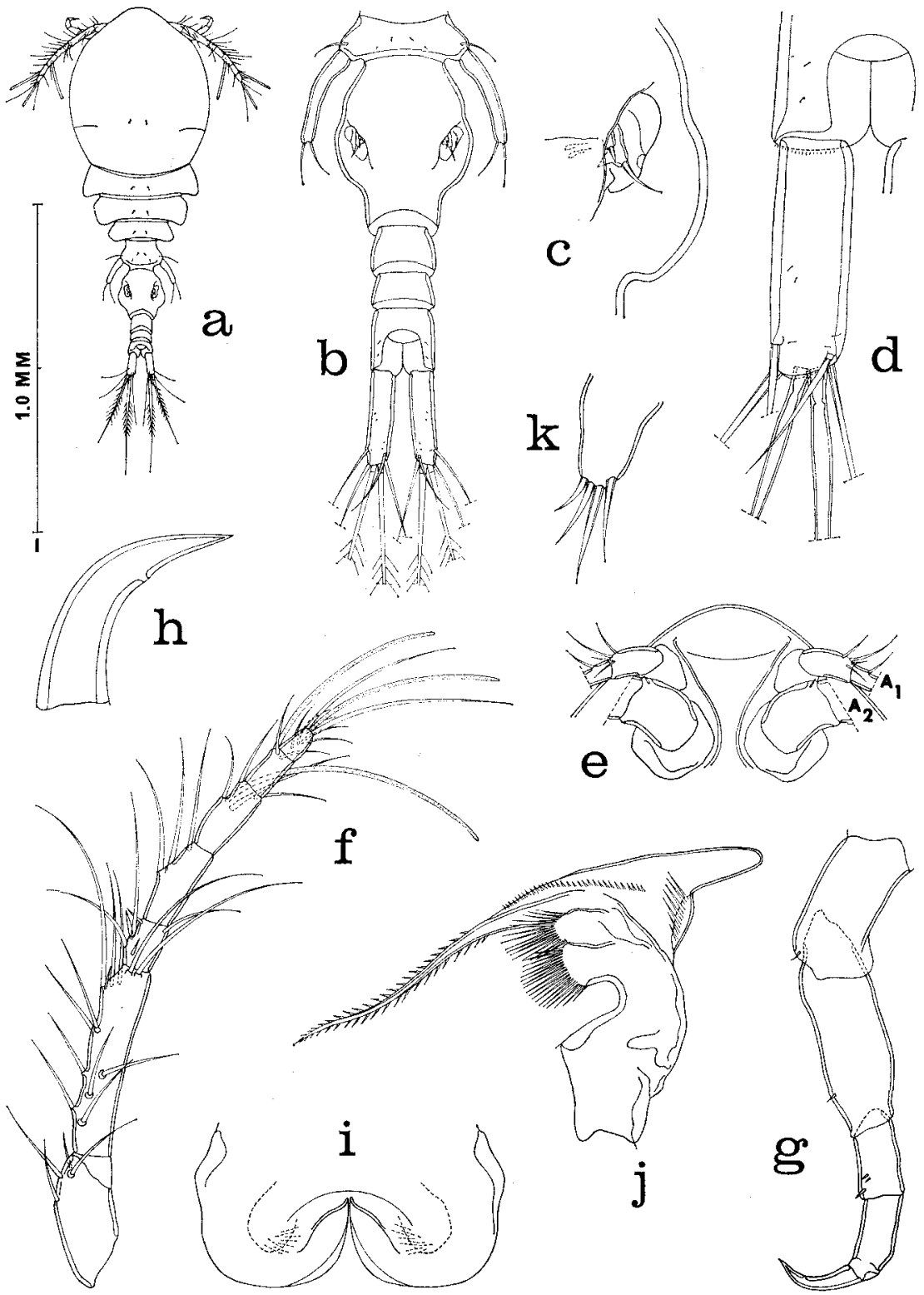

Fig. 10. Odontomolgus forhani n. sp., female. a, dorsal (I); b, urosome, dorsal (B); c, genital area, dorsal (E); d, caudal ramus, dorsal (E); c, rostrum, ventral (G); f, first antenna, with three small round dots indicating positions of three aesthetes added in male, anterodorsal (D); g, second antenna, inner (D); h, claw of second antenna, inner $(\mathrm{H})$; i, labrum and paragnaths, ventral $(\mathbf{C}) ; \mathbf{j}$, mandible, posterior $(\mathrm{C}) ; \mathrm{k}$, first maxilla, anterior $(\mathrm{C})$. 

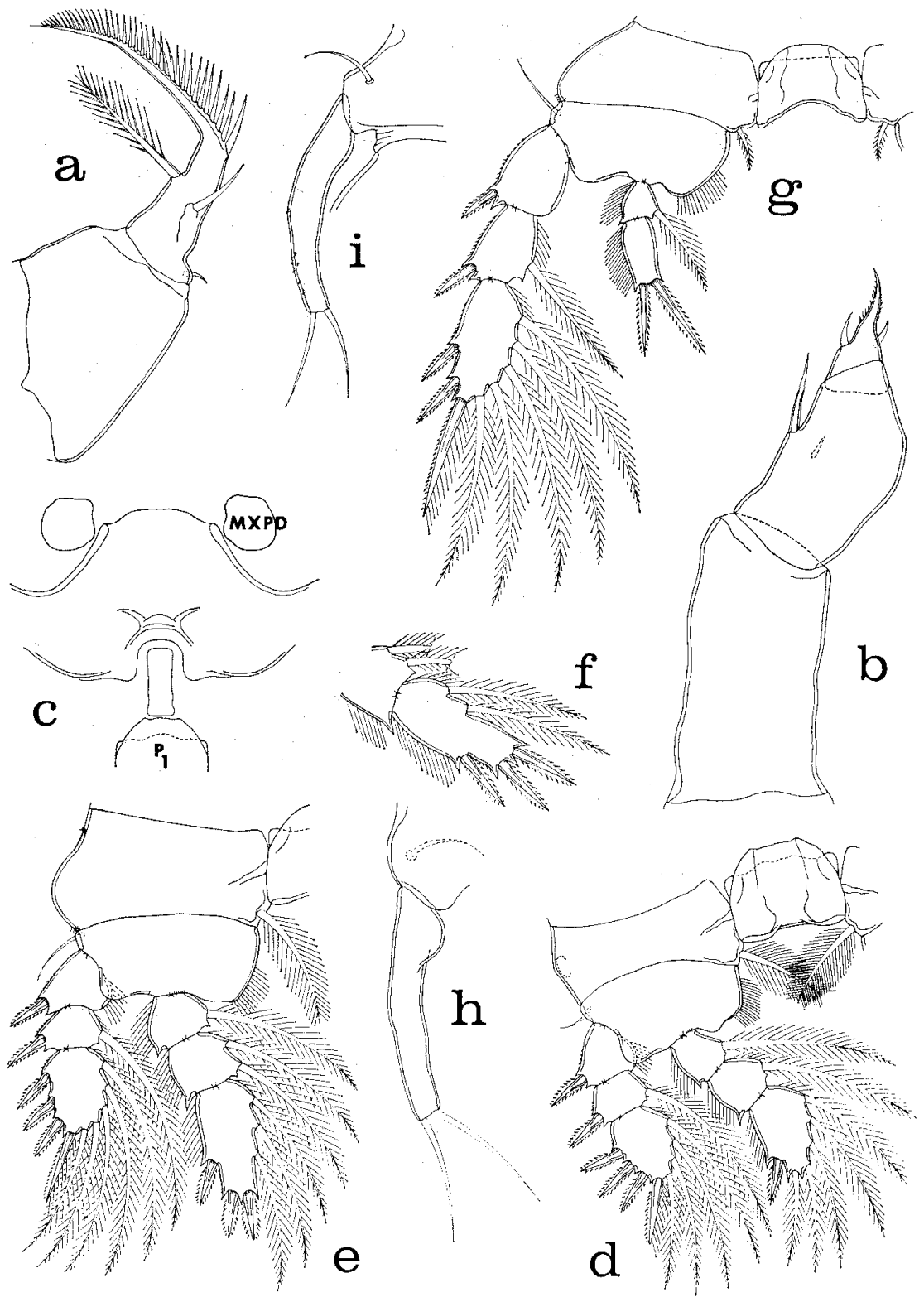

Fig. 11. Odontomolgus forhani n. sp., female. a, second maxilla, posterior (C); b, maxilliped, posterior $(\mathrm{C})$; c, area between maxillipeds and first pair of legs, ventral $(\mathrm{C})$; $\mathrm{d}$, leg 1 and intercoxal plate, anterior (D); e, leg 2, anterior (D); $f$, third segment of endopod of leg 3, anterior (D); g, leg 4 and intercoxal plate, anterior (D); h, leg, 5 , ventral (E); $i, \operatorname{leg} 5$, dorsal (D). 
35 (57 $\mu \mathrm{m}$ along anterior margin), 87, 22, 41, 36, and $15 \mu \mathrm{m}$ respectively. Formula for armature: $4,13,6,3,4+1$ aesthete, $2+1$ aesthete, and $7+1$ aesthete. All setae naked.

Second antenna (fig. $10 \mathrm{~g}$ ) 4-segmented and $216 \mu \mathrm{m}$ long. Formula: 1, 1, 3, and one claw. Setae minute. Fourth segment $46 \mu \mathrm{m}$ along outer edge, $31 \mu \mathrm{m}$ along inner edge, and $18.5 \mu \mathrm{m}$ wide. Claw (fig. $10 \mathrm{~h}$ ) $40 \mu \mathrm{m}$ along axis.

Labrum (fig. 10i) with two broad posteroventral lobes.

Mandible (fig. $10 \mathrm{j}$ ) resembling that of $O$. mundulus but with a row of long spinules proximal to the posteriorly directed digitiform process. Paragnath (its position indicated in figure 10i) a small lobe with a few hairs. First maxilla (fig. 10k) with
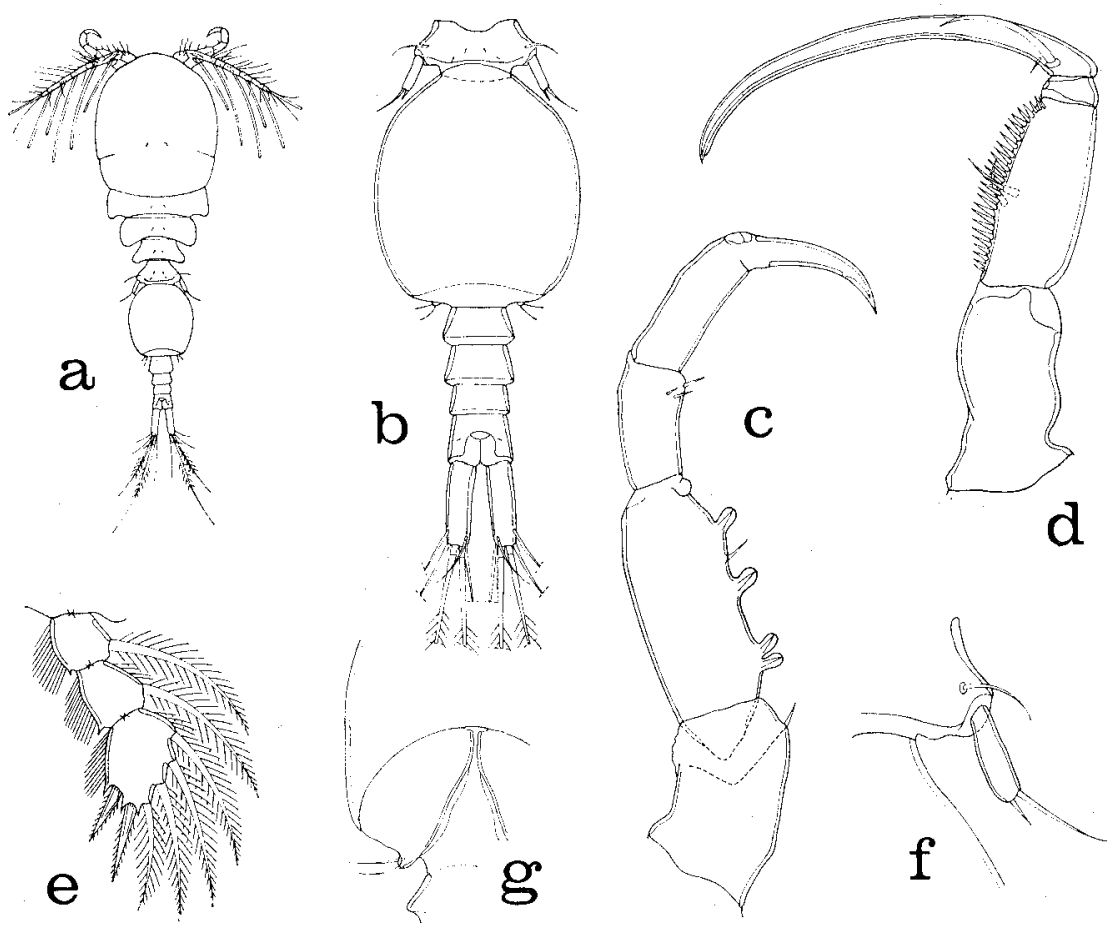

Fig. 12. Odontomolgus forhani n. sp., male. a, dorsal (I); b, urosome, dorsal (B); c, second antenna, inner $(E)$; d, maxilliped, inner (D); e, endopod of leg 1 , anterior (D); f, leg 5 , dorsal (E); g, leg 6 , ventral (G).

four setae. Second maxilla (fig. 1la) armed as in O. mundulus, but inner seta on second segment long with prominent lateral spinules. Maxilliped (fig. 11b) resembling in major respects that of $O$. mundulus.

Ventral area between maxillipeds and first pair of legs (fig. 11c) not protuberant.

Legs 1-4 (figs. 11d, 11e, 11f, 11g) segmented and armed as in other species in genus. Leg 4 with inner coxal seta $22 \mu \mathrm{m}$ long and barbed. Inner margin of basis with row of hairs. Exopod of leg $4135 \mu \mathrm{m}$ long. Endopod with first segment $16.5 \times 18.5 \mu \mathrm{m}$ (without terminal processes), inner plumose seta $34 \mu \mathrm{m}$; second segment $32 \times 16 \mu \mathrm{m}$, its two terminal barbed spines $31 \mu \mathrm{m}$ (outer) and $35 \mu \mathrm{m}$ (inner). 
Both segments haired along outer edge.

Leg 5 (figs. $11 \mathrm{~h}, 11 \mathrm{i}$ ) with elongate free segment $79-104 \mu \mathrm{m}$, long, $19 \mu \mathrm{m}$ wide at slight proximal inner expansion, and $9 \mu \mathrm{m}$ wide distally. Two terminal naked setae $41 \mu \mathrm{m}$ and $44 \mu \mathrm{m}$. Segment usually unornamented, but one female with segment $104 \times 15.5 \mu \mathrm{m}$ and bearing minute spines distally (fig. 11i).

Leg 6 represented by two setae and spiniform process on genital area (fig. 10c).

Living specimens in transmitted light opaque, eye red.

Male.-Body (fig. 12a) with cephalosome slightly more broadly rounded anteriorly than in female. Length (without setae on caudal rami) $0.97 \mathrm{~mm}(0.92-1.02$ $\mathrm{mm}) \times 0.30 \mathrm{~mm}(0.29-0.32 \mathrm{~mm})$, based on 10 specimens in lactic acid. Ratio of length to width of prosome 1.72:1. Ratio of length of prosome to that of urosome $1.17: 1$.

Segment of leg 5 (fig. 12b) $44 \times 94 \mu \mathrm{m}$. Genital segment $198 \times 169 \mu \mathrm{m}$, with rounded lateral margins in dorsal view. Four postgenital segments from anterior to posterior $31 \times 60 \mu \mathrm{m}, 34 \times 57 \mu \mathrm{m}, 26 \times 52 \mu \mathrm{m}$, and $44 \times 58 \mu \mathrm{m}$.

Caudal ramus resembling that of female but smaller, $78 \times 21 \mu \mathrm{m}$, ratio $3.71: 1$.

Fine ornamentation of body as in female.

Rostrum similar to that of female.

First antenna like that of female but three long aesthetes added, two on second segment and one on fourth segment (fig. 10f), so that formula is: $4,13+2$ aesthetes, $6,3+1$ aesthete, $4+1$ aesthete, $2+1$ aesthete, and $7+1$ aesthete. Second antenna (fig. 12c) resembling that of female, but having along inner edge of second segment four, rarely five, spiniform processes with broad hyaline lamellae.

Labrum, mandible, paragnath, first maxilla, and second maxilla like those of female. Maxilliped (fig. 12d) in general similar to that of O. mundulus. Claw 164 $\mu \mathrm{m}$ along its axis. Two slender setae on second segment, one smooth, other with very small barbules.

Ventral area between maxillipeds and first pair of legs as in female.

Legs $1-4$ as in female except for formula I, I, 4 on third segment of endopod of leg 1 (fig. 12e).

Leg 5 (fig. 12f) smaller than in female, free segment $28 \times 8 \mu \mathrm{m}$, its two setae $10 \mu \mathrm{m}$ and $30 \mu \mathrm{m}$.

Leg 6 (fig. 12g) a posteroventral flap on genital segment bearing two naked setae about $21 \mu \mathrm{m}$ long.

Spermatophore not observed.

Living specimens colored as in female.

Etymology.-The species is named for Mr. Thomas Forhan, who through SCUBA diving obtained many Moluccan invertebrates that were hosts for copepods.

Comparison with other species in genus.- Seven species of Odontomolgus have been described, all from scleractinian corals (Alveopora, Fungia, Halomitra, Pavona, and Psammocora) in the Indo-Pacific. Odontomolgus forhani is distinct from all of these previously known species. The proportions of the female genital segment constitute a readily observable distinguishing feature. In Odontomolgus actinophorus Humes and 
Frost, 1964, O. campulus Humes and Ho, 1968, O. decens Humes, 1978, O. fultus Humes, 1978, O. mundulus Humes, 1974, and O. scitulus Humes, 1973, the genital segment is wider than long, rather than longer than wide as in the new species. The length of the free segment of leg 5 in the female is also useful in separating $O$. forhani from its congeners. In $O$. actinophorus this segment is much longer $(141 \mu \mathrm{m})$ than in the new species, while in $O$. campulus, $O$. decens, $O$. fultus, O. mundulus, and $O$. scitulus it is much shorter (less than $45 \mu \mathrm{m}$ ). In the female of Odontomolgus rhadinus Humes and Ho, 1967, the genital segment is about as long as wide and the length of the free segment of leg 5 is similar to that in O.forhani. However, the shape of the female genital segment and the row of dentiform spinules on the second segment of the male second antenna in $O$. rhadinus distinguish this species from $O$. forhani.

\section{REFERENCES}

Humes, A.G. 1973. Cyclopoid copepods (Lichomolgidae) from fungiid corals in New Caledonia. Zool. Anz., 190 (5/6): 312-333.

—_ 1974. Odontomolgus mundulus n. sp. (Copepoda, Cyclopoida) associated with the scleractinian coral genus Alveopora in New Caledonia. Trans. Amer. Micros. Soc., 93 (2) : 153-162.

_ 1978. Lichomolgid copepods (Cyclopoida) associated with fungiid corals (Scleractinia) in the Moluccas. Smithsonian Contrib. Zool., no. 253, pp. 1-48.

Humes, A.G. and B.W. Frost 1964. New lichomolgid copepods (Cyclopoida) associated with alcyonarians and madreporarians in Madagascar. Cahiers ORSTOM Océanographie, 1963, 6 (série Nosy Bé II): 131-212.

Humes, A.G. and J.-S. Ho 1967. New cyclopoid copepods associated with the coral Psammocora contigua (Esper) in Madagascar. Proc. U.S. Nat. Mus,, 122 (3586): 1-32.

__ 1968a. Lichomolgid copepods (Cyclopoida) associated with corals in Madagascar. Bull. Mus. Comp. Zool., Harvard Univ., 136 (10): 353-413.

—_ 1968b. Xarifiid copepods (Cyclopoida) parasitic in corals in Madagascar. Bull. Mus. Comp. Zool., Harvard Univ., 136 (11): 415-459.

Humes, A.G. and J.H. Stock 1972. Preliminary notes on a revision of the Lichomolgidae, cyclopoid copepods mainly associated with marine invertebrates. Bull. Zool. Mus., Univ. Amsterdam, 2 (12): 121-133.

1973. A revision of the family Lichomolgidae Kossmann, 1877, cyclopoid copepods mainly associated with marine invertebrates. Smithsonian Contrib. Zool., no. 127, pp. 1-368.

Kossmann, R. 1877. Entomostraca (1. Theil: Lichomolgidae). In: Zoologische Ergebnisse einer im Auftrage der Königlichen Academie der Wissenschaften zu Berlin ausgeführten Reise in die Küstengebiete des Rothen Meeres, erste Hälfte, IV, pp. 1-24.

Sebastian, M.J. and N.K. Pillai 1974. Two new genera of clausiid copepods, Indoclausia and Stockia. Crustaceana, 26 (1): 80-88.

Stock, J.H. 1966. Cyclopoida siphonostoma from Mauritius (Crustacea, Copepoda). Beaufortia, 13 (159): 145-194. 